International Journal of Advanced Geosciences, $2(2)(2014) 72-81$
International Journal of Advanced Geosciences
Journal home page: www.sciencepubco.com/index.php/IJAG
doi: $10.14419 /$ ijag.v2i2.2304
Research Paper

\title{
Hydrogeophysical assessment of some parts of Anambra basin, Nigeria
}

\author{
Anakwuba, E. K. *, Nwokeabia, C. N., Chinwuko, A. I. And Onyekwelu, C.U \\ Department of Geological Sciences, Nnamdi Azikiwe University; P. M. B. 5025 Awka, Nigeria \\ *Corresponding author E-mail: Emmaanakwuba@Yahoo.Com
}

\begin{abstract}
An electrical resistivity investigation has been carried out in thirteen communities within the Anambra Basin in order to determine the depth to the water table and groundwater flow in the area. Vertical electrical sounding (VES) curves were obtained across the area using the Schlumberger configuration. Both manual and computer interpretations of the resistivity data show basically three to five geo-electric units within the study area. The lowermost layer with the resistivity range of $144-1500 \mathrm{Ohm}-\mathrm{m}$ and depth of $14.9-166.41 \mathrm{~m}$ represents the aquifer. The water table map indicates multi flow direction and correlates favourably with the topography of the area. It was observed that the hydraulic conductivity obtained ranges from $6.67 \times 10-4$ to $6.944 \times 10-3 \mathrm{~m} /$ day while the transmissivity ranges from 0.048 to $0.590 \mathrm{~m} 2 /$ day within the study area.
\end{abstract}

Keywords: Groundwater, Resistivity Survey, Aquifer, Exploration, Schlumberger, Sounding.

\section{Introduction}

The study area lies within latitudes $6^{0} 01^{1}$ and $6^{0} 20^{1} \mathrm{~N}$ and longitudes $7^{0} 00^{1}$ and $7^{0} 19^{1} \mathrm{E}$, covering parts of Enugu and Anambra states (Fig. I). The communities within the area have peculiar water problems. Some of them do not have surface waters and have depended on harvested rainfall for sustenance during the dry seasons. Some of the available surface waters are being polluted by both natural and anthropogenic means. As a result of these, and especially the satisfaction of the demands of the growing population of the area, the search for a portable source of water becomes apparent.

However, with the recent technological development, groundwater has become the choice for both domestic and industrial water supply in the area. Groundwater is a major source of clean drinking water and it accounts for about $98 \%$ of the world's fresh water (Mather, 1984 and Montgomery, 2000).

Electrical resistivity method is one of the geophysical methods used in groundwater exploration. The subsurface information inferred from this survey give a better knowledge of the aquifer systems and a more realistic picture of groundwater potential of any area (Amaresh et al., 2006). The technique has been successfully used in investigating groundwater potential in different geological settings. Also this method was used to explore for groundwater in a sedimentary environment (Emenike, 2000). In this study, vertical electrical sounding was used to establish the occurrence and flow of groundwater within some parts of Anambra Basin.

\section{Geological setting}

The Anambra Basin is a Cretaceous/Tertiary basin, which is the structural link between the Cretaceous Benue Trough and the Ter tiary Niger Delta basin (Lucas and Ishiekwene. 2010). It is bordered by the Abakaliki anticlinorium to the east, the basement rock and the Benue hinge line to the north and northwest respectively (Fig. II). The basin originated as a fault- controlled depression within the basement complex of African shield. Structurally, it is an interior fracture basin. Maximum sedimentation in the depression occurred in the Benue Trough and its echelon equivalent, the Abakaliki trough. However, there was a structural inversion of the Abakaliki Trough during the Coniacian - Santonian times. This movement led to the formation of two depressions on the flanks of the anticlinorium; the narrow Afikpo syncline on the southeast and much wider Anambra basin on the northwest (Lucas and Ishiekwene, 2010; Grant, 1971; Murat, 1970). These depressions became the point of foci after the Santonian.

The stratigraphic history of the region is characterized by three sedimentary phases ( Aboh and Osazuwa, 2000) during which the axis of the sedimentary basin shifted. These three phases were: (a) the Abakaliki - Benue phase (Aptian to Santonian), (b) the Anambra- Benin phase (Campanian to Mid Eocene) and the Niger Delta phase (Late Eocene - Pliocene). The more than $3000 \mathrm{~m}$ of sediments comprising the Asu River Group, Eze-Aku and Awgu Formations were deposited during the first phase in the Abakaliki - Benue Basin, Benue Valley and the Calabar Flank. The second sedimentary phase resulted from the Santonian folding and uplift of the Abakaliki region and dislocation of the depocenter into the Anambra platform and Afikpo region. The resulting succession comprises the Nkporo Group, Mamu Formation, Ajali Sandstone, Nsukka, Imo and Ameki Formations. The third sedimentary phase credited for the formation of the petroliferous Niger Delta, commenced in the Late Eocene. 


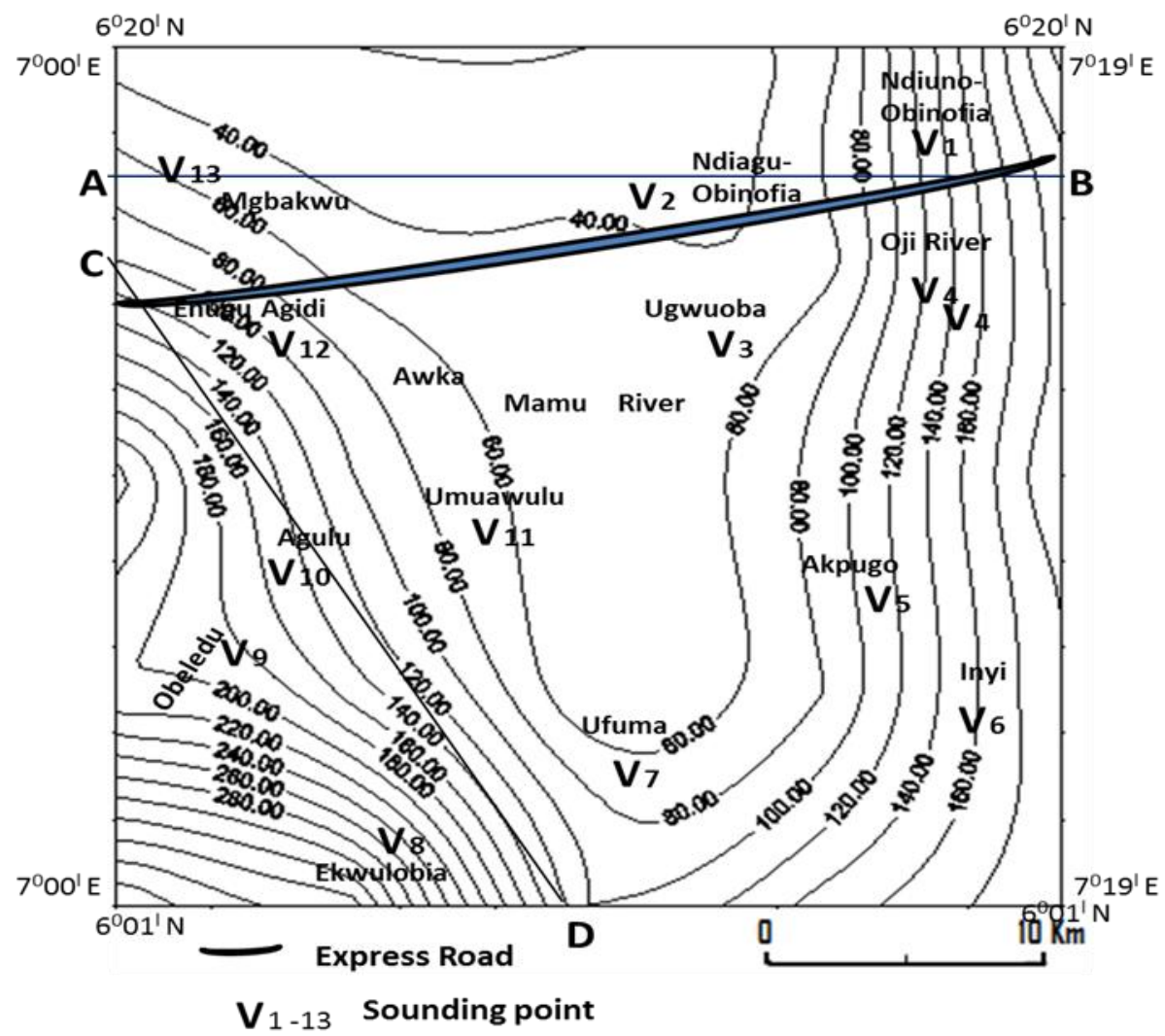

Fig. 1: Topographic Map Showing Sounding Points within the Study Area (Contour Interval 10m)

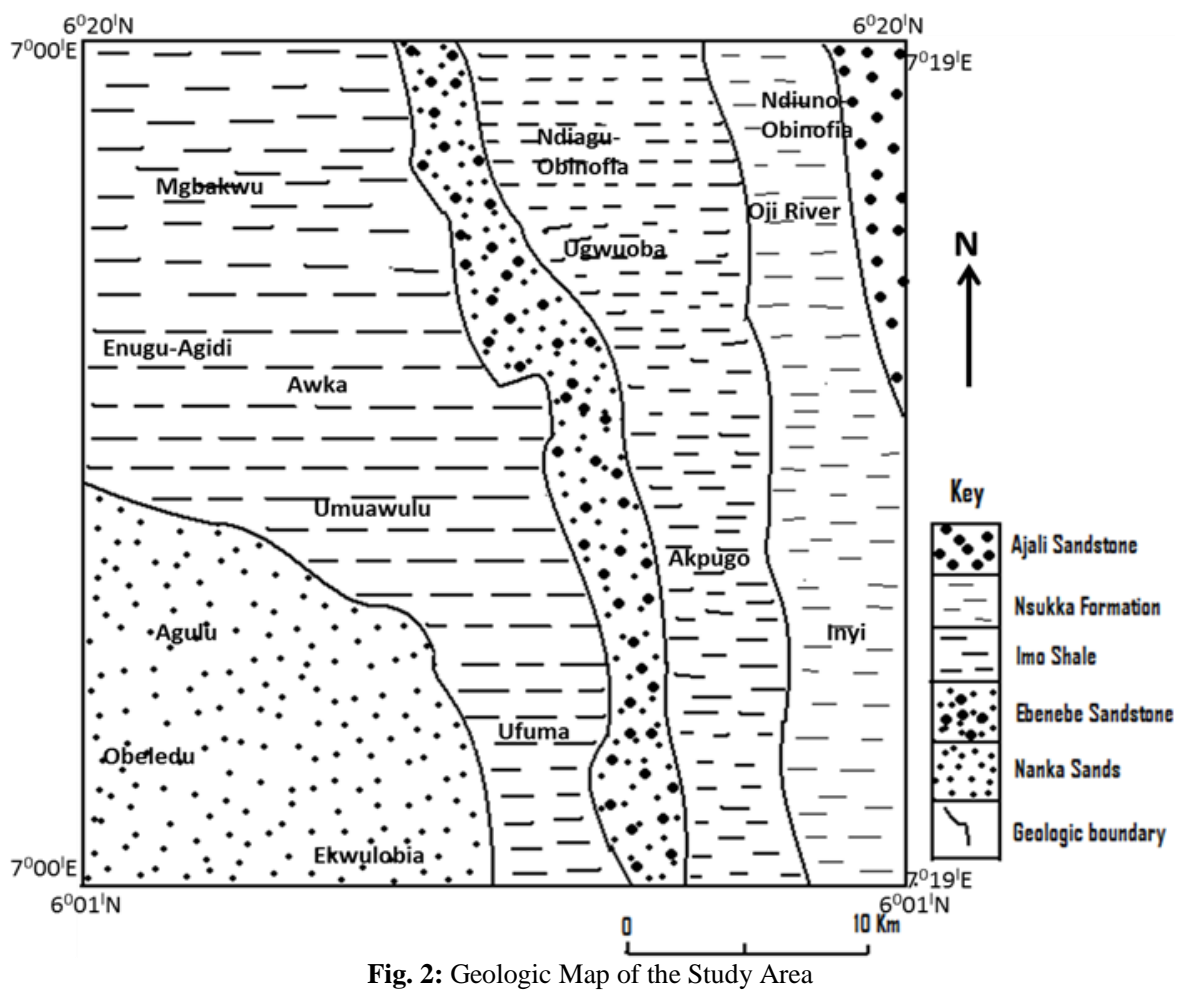

\section{Methodology}

The electrical resistivity method was used for the investigation. A total of thirteen VES stations were surveyed in the study area. The resistivities of the layers were measured using the ABEM SAS 300 B Terrameter and SAS 2000 Booster. The Schlumberger electrode configuration having a maximum current electrode spread of $500 \mathrm{~m}$ was used. The apparent resistivity values obtained from the measurement were plotted against half the current electrode spacing on a bi-logarithmic graph in order to determine the apparent resistivities and thicknesses of various layers penetrated. This approach has been applied extensively in groundwater exploration by Aboh and Osazuwa, 2000; Edet, and Okereke, 2002; . Ekwe et al., 2002; Onwuemesi and Egboka, 2006; Anudu et al., 2008; Mohammed et al., 2008; Oseji and Ujuanbi, 2009. Okoro et al., 2010; Akpoborie et al. 2011; Ezeh, 2011. The resistivity curves were interpreted quantitatively by matching small segments of the field curves using two-layer model curves and the corresponding auxil- 
iary curves. The resistivity data were interpreted manually using partial curve matching method as well as using IXID that was developed by Interpex Limited (See Figures 3 5).

\section{Results and discussion}

\subsection{Geo-electric sections}

Thirteen geo-electrical sounding stations were covered during the survey. The stations were represented as VES1-13 respectively. The interpretation of the data was based on computer iteration. Each geo-electric station derived consists of about three to five geo-electric layers. Each layer is definable over some boundary thickness, which has a single resistivity value throughout. Table 1 shows the detailed descriptions of the VES results obtained.

Table 1 and Fig. 3 show typical geo-electric sections of (VES 2, 4, 5,6 and 11) with a typical K-curve type. The first layers have resistivity ranging from 280 to $950 \mathrm{Ohm}-\mathrm{m}$ with thickness range of 1 to $3 \mathrm{~m}$ and were interpreted as top soil. The second layers have higher resistivity values ranging from 420 to $7850 \mathrm{Ohm}-\mathrm{m}$ which implies low conductivity. The thicknesses range from $13.6 \mathrm{~m}$ to $111 \mathrm{~m}$ and were interpreted as dry sandstone. The last layers had reduced resistivity values of 144 to $950 \mathrm{Ohm}-\mathrm{m}$ which indicated presence of water (Figures 3-5).
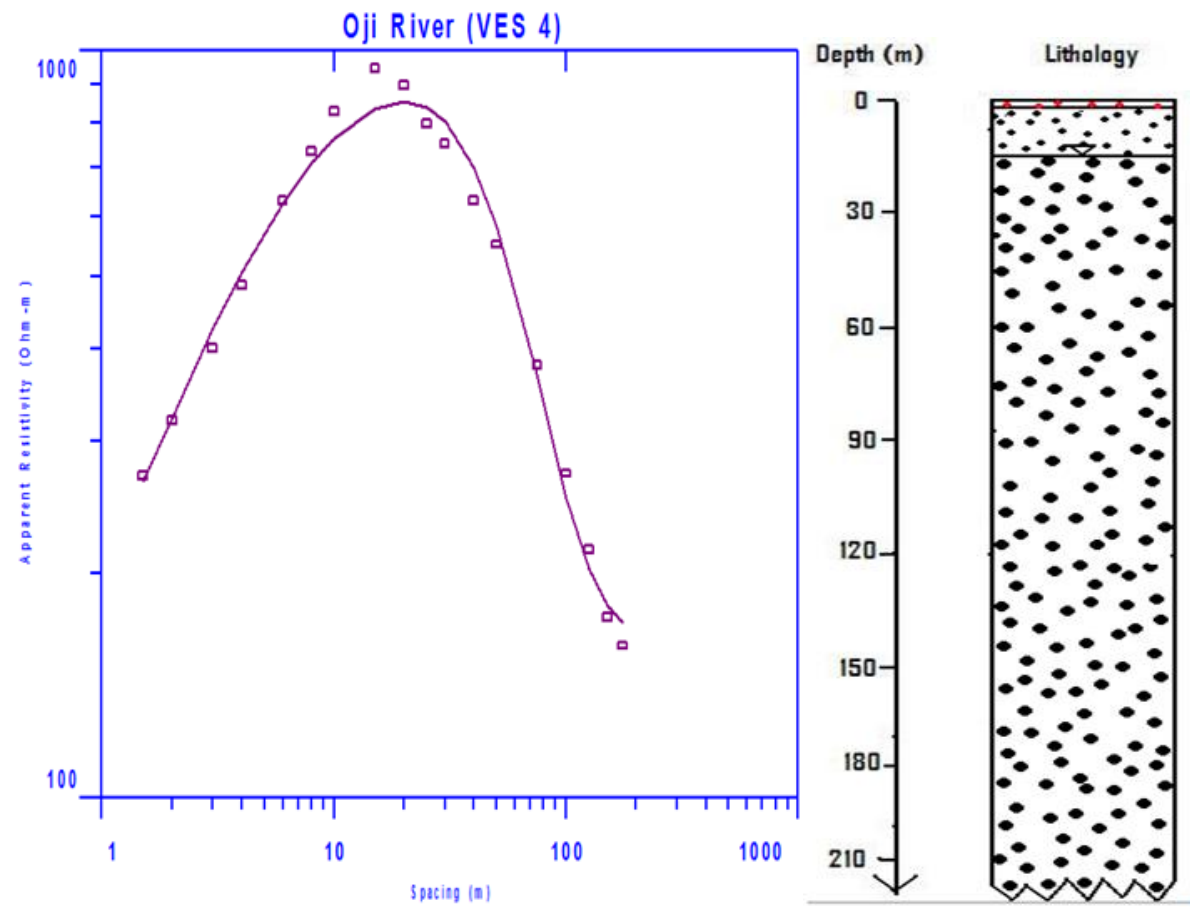

Description

Top soil (130 Ohm-m)

Dry sandstone (15 Ohm-m)

Fig. 3: A Typical 3-Layer VES Curve and Geo-Electric Section
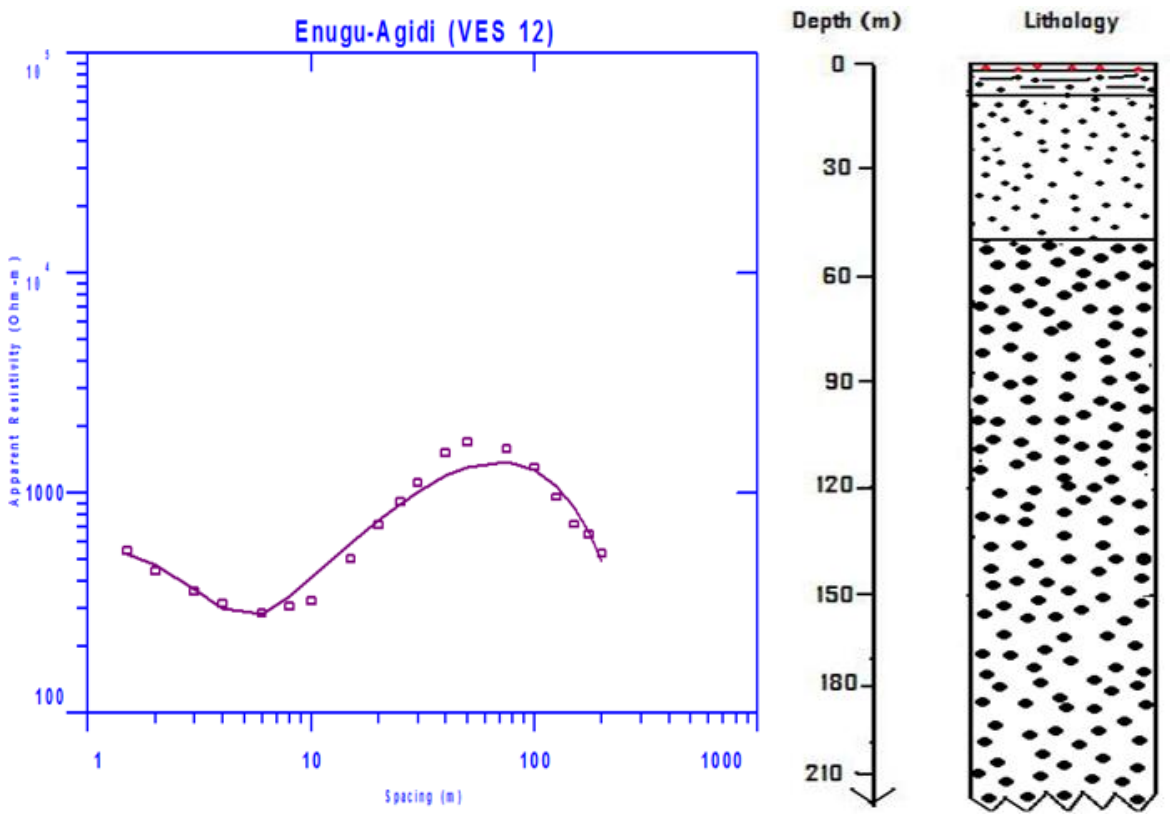

Description

Top soil (700 Ohm-m) Clayey sandstone $(290 \mathrm{Ohm}-\mathrm{m})$

Dry sandston

(1800 Ohm-m)

Fig. 4: A Typical 4-Layer VES Curve and Geo-Electric Section 


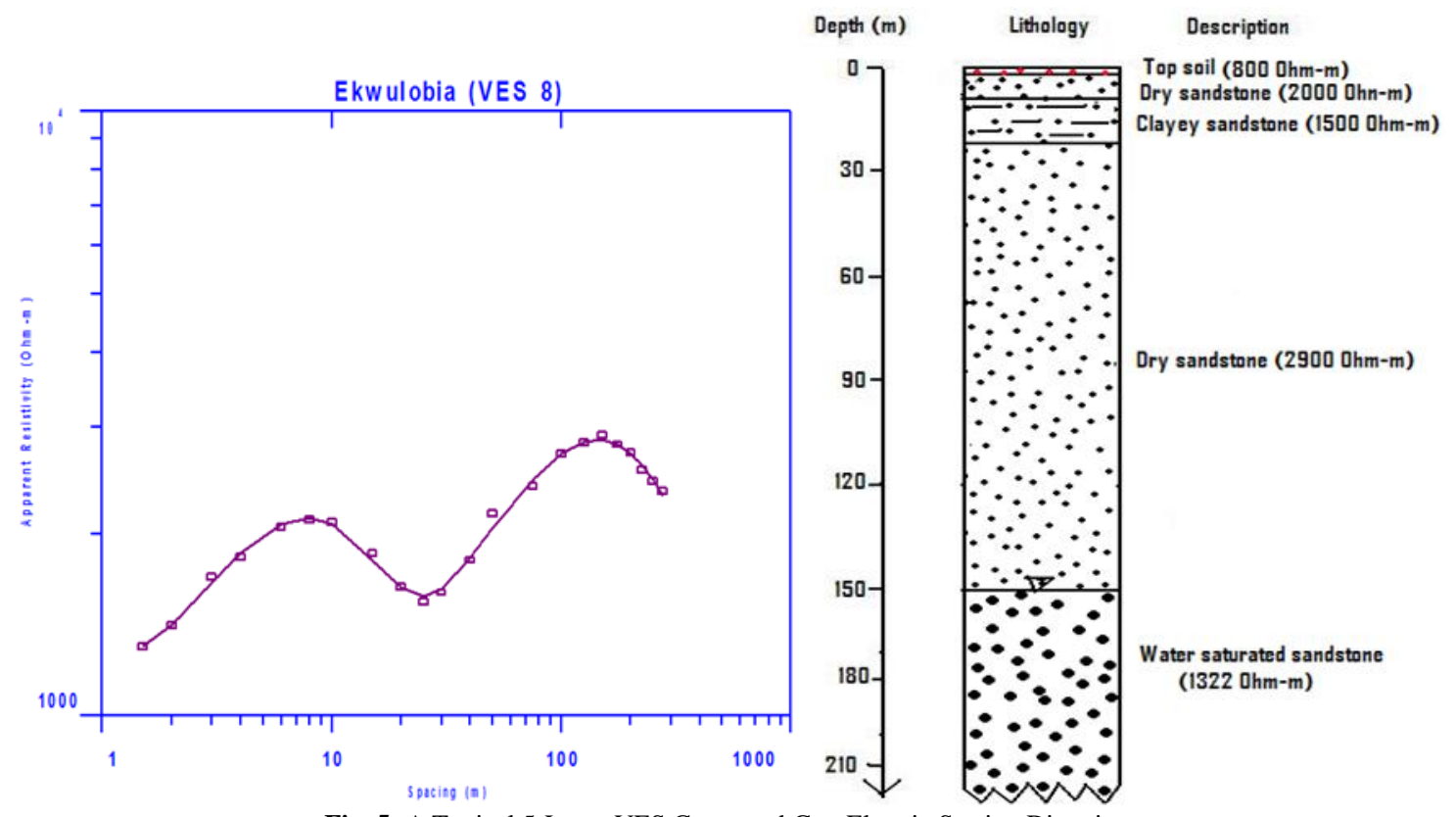

Fig. 5: A Typical 5-Layer VES Curve and Geo-Electric Section Direction

Table 1: Summary of VES Results

\begin{tabular}{|c|c|c|c|c|c|}
\hline VES Station/Curve Type & Layer & Apparent Resistivity (m) & Thickness (m) & Depth $(\mathrm{m})$ & Lithology \\
\hline \multirow[t]{3}{*}{$(\mathrm{VES} 1) / \mathrm{HK}$} & 1 & 1550 & 1.2 & 1.2 & Top soil \\
\hline & 2 & 450 & 4.8 & 6 & Clayey sand \\
\hline & 3 & 10010.1 & 114 & 120 & Dry sandstone \\
\hline \multirow[t]{3}{*}{$($ VES 2) / $\mathrm{K}$} & 1 & 280 & 1 & 1 & Top soil \\
\hline & 2 & 2400 & 111 & 112 & Dry sandstone \\
\hline & 3 & 950 & & & Water saturated sandstone \\
\hline \multirow[t]{4}{*}{ (VES 3) / HK } & 1 & 1850.01 & 0.8 & 0.8 & Top soil \\
\hline & 2 & 950 & 4.7 & 5.5 & Clayey sand \\
\hline & 3 & 6000 & 69.5 & 75 & Dry sandstone \\
\hline & 4 & 1220 & & & Water saturated sandstone \\
\hline \multirow[t]{3}{*}{ (VES 4) / K } & 1 & 250 & 1.4 & 1.4 & Top soil \\
\hline & 2 & 1300 & 13.6 & 15 & Dry sandstone \\
\hline & 3 & 144 & & & Water saturated sandstone \\
\hline \multirow[t]{3}{*}{$($ VES 5 )/ K } & 1 & 350 & 3 & 3 & Top soil \\
\hline & 2 & 1600 & 47 & 50 & Dry sandstone \\
\hline & 3 & 180 & & & Water saturated sandstone \\
\hline \multirow{2}{*}{ (VES6) / K } & 2 & 7850 & 88 & 90 & Dry sandstone \\
\hline & 3 & 1500 & & & Water saturated sandstone \\
\hline \multirow[t]{4}{*}{$($ VES 7 )/ HK } & 1 & 1350 & 1.1 & 1.1 & Top soil \\
\hline & 2 & 958 & 4.9 & 5 & Clayey sand \\
\hline & 3 & 2400 & 35 & 40 & Dry sandstone \\
\hline & 4 & 760 & & & Water saturated sandstone \\
\hline \multirow[t]{5}{*}{ (VES 8) / KHK } & 1 & 800 & 0.7 & 0.7 & Top soil \\
\hline & 2 & 2000 & 5.3 & 6 & Dry sandstone \\
\hline & 3 & 1500 & 19 & 25 & Clayey sand \\
\hline & 4 & 2900 & 65 & 150 & Dry sandstone \\
\hline & 5 & 1250.11 & & & Water saturated sandstone \\
\hline \multirow[t]{5}{*}{ VES 9/ KHK } & 1 & 680 & 1.5 & 1.5 & Top soil \\
\hline & 2 & 1702 & 4.5 & 6 & Dry sandstone \\
\hline & 3 & 1053 & 6.5 & 12.5 & Clayey sand \\
\hline & 4 & 3221 & 153.91 & $166 . .41$ & Dry sandstone \\
\hline & 5 & 1125 & & & Water saturated sandstone \\
\hline \multirow[t]{2}{*}{ (VES 10) / HK } & 1 & 1353 & 1.5 & 1.5 & Top soil \\
\hline & 4 & 768 & & & Water saturated sandstone \\
\hline \multirow[t]{3}{*}{ (VES 11) / K } & 1 & 306 & 1.1 & 1.1 & Top soil \\
\hline & 2 & 420 & 53.9 & 55 & Dry sandstone \\
\hline & 3 & 466 & & & Water saturated sandstone \\
\hline \multirow[t]{4}{*}{ (VES 12) / HK } & 1 & 550 & 1.03 & 1.03 & Top soil \\
\hline & 2 & 290 & 4.97 & 6 & Clayey sand \\
\hline & 3 & 1800 & 49 & 55 & Dry sandstone \\
\hline & 4 & 420 & & & Water saturated sandstone \\
\hline \multirow[t]{4}{*}{ VES 13 / HK } & 1 & 526 & 1.5 & 1.5 & Top soil \\
\hline & 2 & 283 & 5.5 & 7 & Clayey sand \\
\hline & 3 & 3000 & 93 & 100 & Dry sandstone \\
\hline & 4 & 709 & & & Water saturated sandstone \\
\hline
\end{tabular}




\subsection{Correlation of geo-electric sections}

The results of the interpretation were used to construct two interpretive sections EF and GH, taken in the north-south and west-east directions respectively (Figure. VI).The sections (Figs.VIa and VIb) reveal that the aquifers are overlain in places by materials with variable thickness and resistivity parameters. In the north- east section (Figure. 6a), the resistivity of materials overlying the aquiferous units which are dry sandstone ranges from 1300 to $10,010.1 \mathrm{Ohm}-\mathrm{m}$. The depth to the top of the aquifer varies from 15 to $120 \mathrm{~m}$. The high resistivity of the top layers may correspond to the unsaturated zone. The west-east section (Fig. VIb) reveals that depth to the aquifer ranges from 15 to $112 \mathrm{~m}$.

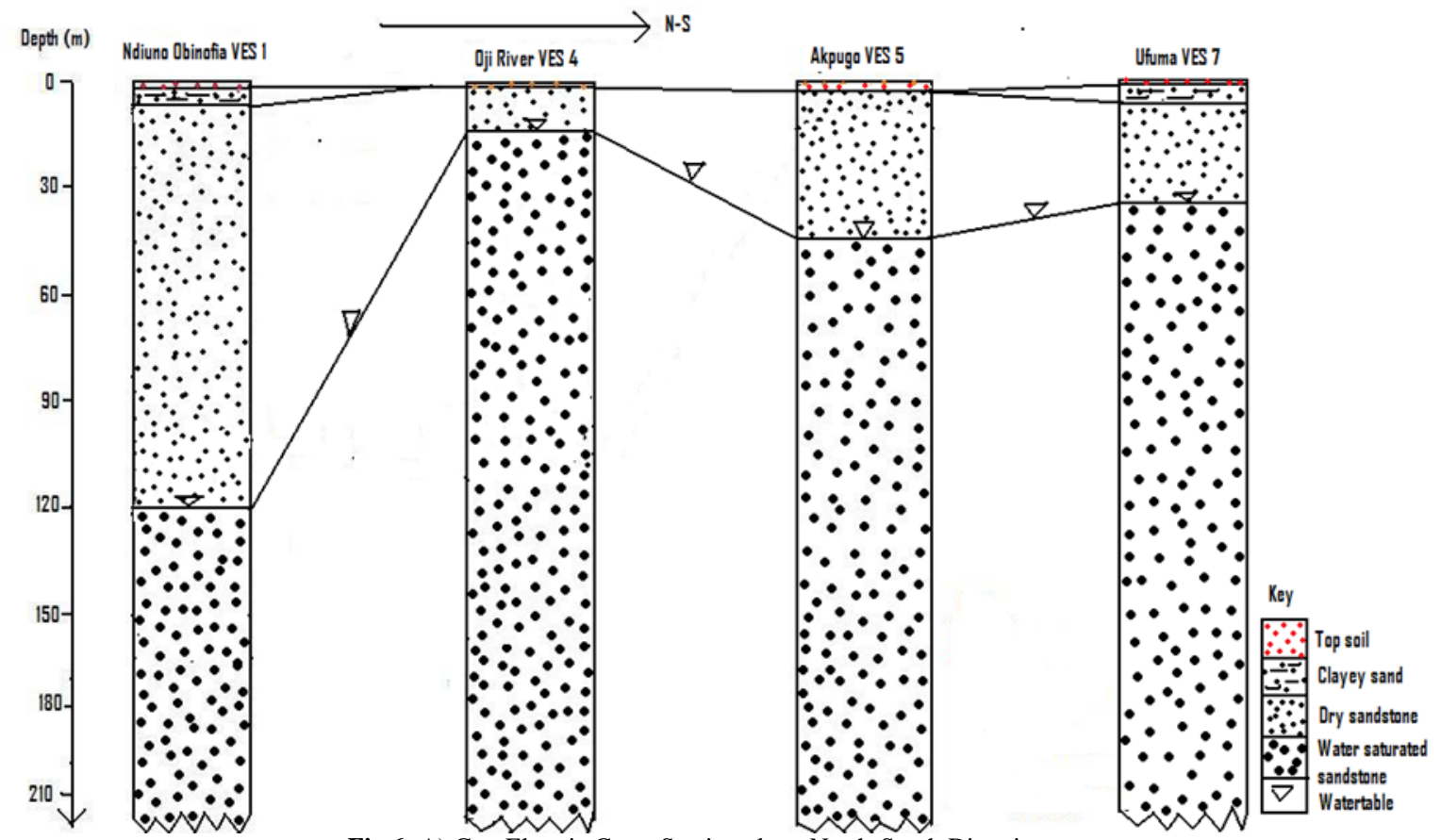

Fig.6: A) Geo-Electric Cross Section along North-South Direction

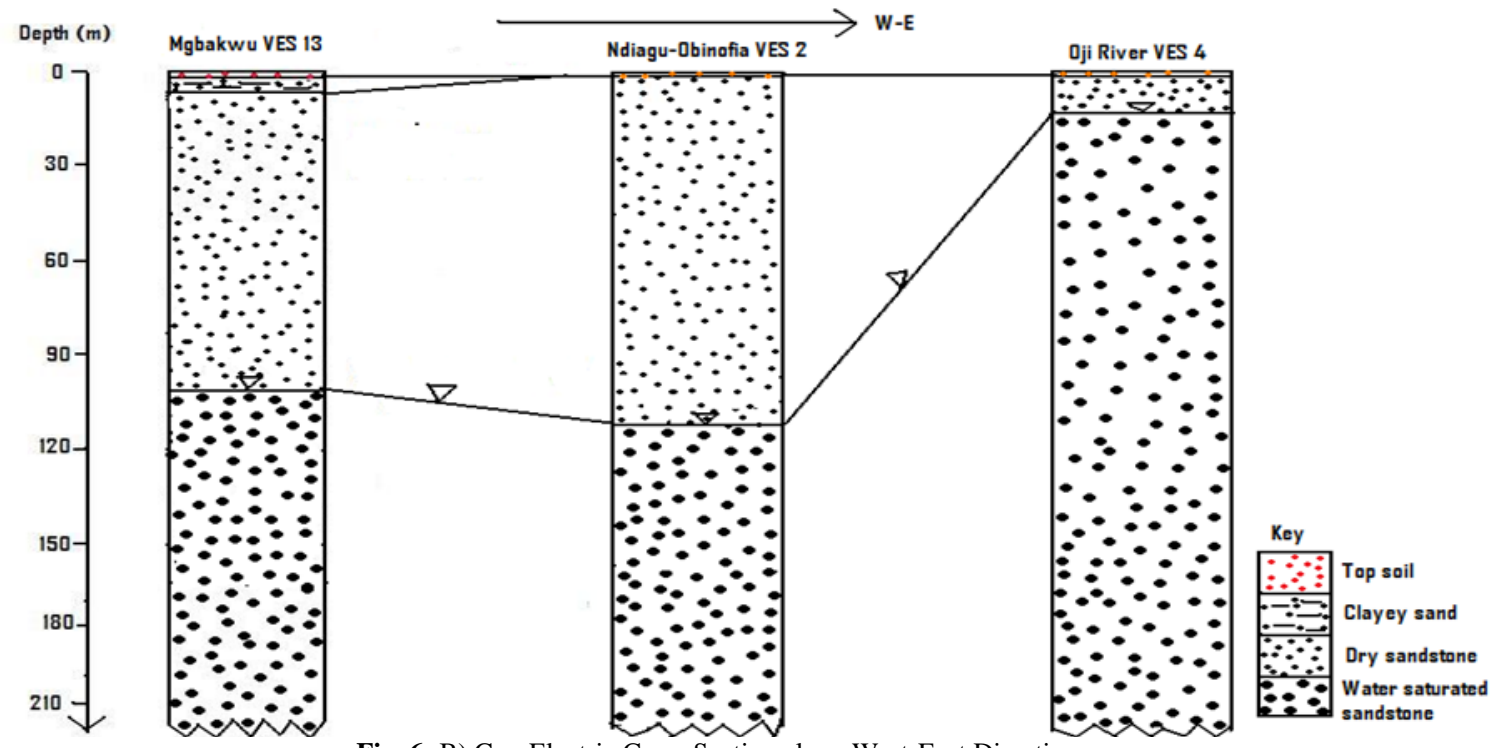

Fig. 6: B) Geo-Electric Cross Section along West-East Direction

\subsection{Comparison between geo-electric section and bore- hole log}

The comparison of lithologic section obtained from borehole located at Obeledu and the interpreted geo-electric units from the same Obeledu (Fig. 7), showed that the top soil in the lithologic section is $0 \mathrm{~m}$ while in geo-electric section it is $1.5 \mathrm{~m}$. In the under- lying layers, the geo-electric units show suppression/merging of some lithologic units from the borehole. This is due to the fact that geo-electric units are not the same as lithologic units. Also, different lithologic units with similar resistivities would be merged as one geo-electric unit. Moreso, the watertable varies a little from the geo-electric unit with value of depth being $166.41 \mathrm{~m}$ in the geo-electric section and 160m in the lithologic unit (Figs. 6-7). 


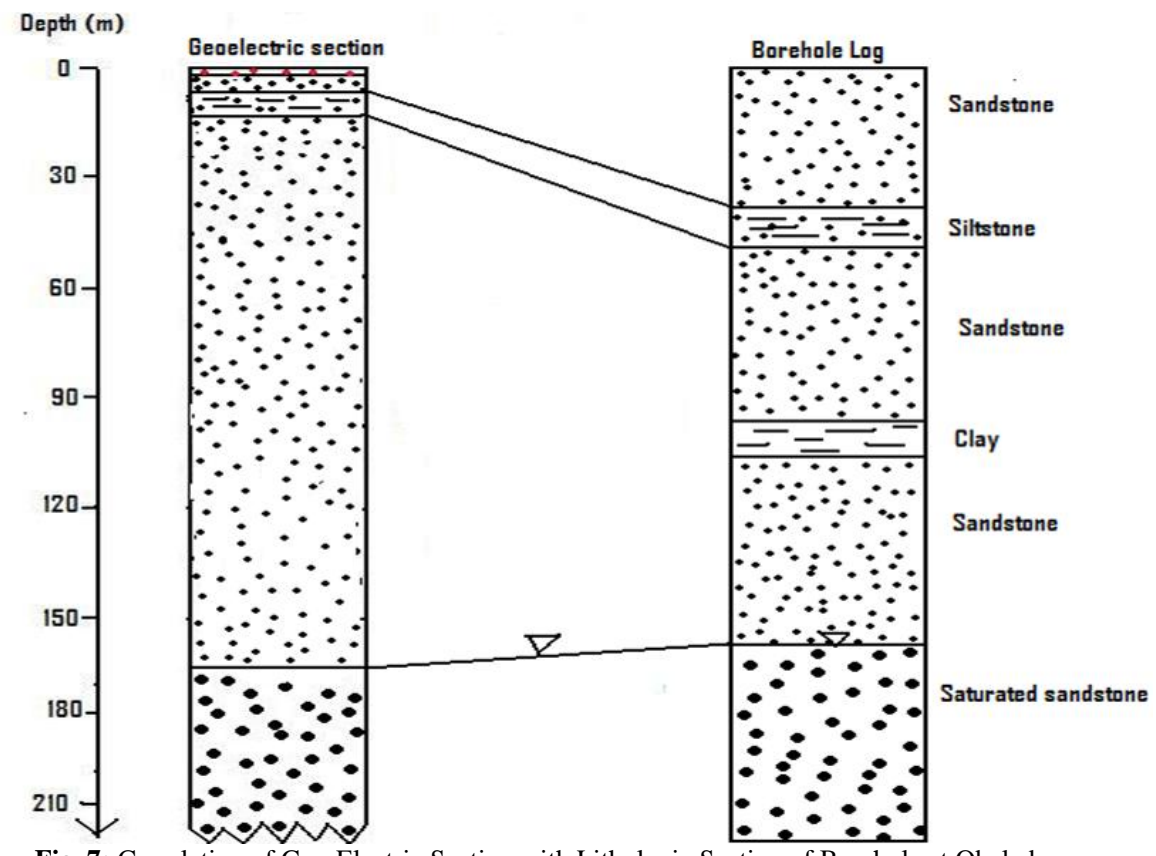

Fig. 7: Correlation of Geo-Electric Section with Lithologic Section of Borehole at Obeledu

\subsection{Water table map}

The depth to the top of the aquifer deduced from the geo-electric section was subtracted from the topographic elevation measured from the mean sea level. The differences showed areas with negative and positive values relative to the mean sea level. The areas with positive values include, Ndiuno Obinofia, Oji River, Akpugo, Inyi, Ufuma, Ekwulobia, Obeledu, Agulu, Umuawulu and Enugu Agidi. While Ndiagu Obinofia, Ugwuoba and Mgbakwu have negative values (Table II). The negative and positive values signify areas with low and high topographic elevations respectively. The values were plotted and contoured on the survey map to give water table contour map (Fig. VIII). Two cross sections A-B and C-D were taken across the water table and topographic maps.

The first cross section A-B runs through Mgbakwu, Ndiagu Obinofia, and Oji River areas in the west-east (W-E) direction. Here, it was observed that the water table follows topography to an extent and groundwater flows in the West-East direction (Fig. $\mathrm{IXa}$ ). It was also observed that the hydraulic flow is higher at Oji River area because of high intensity of the water table contour than in Mgbakwu area were the intensity of the water table contour is less. Also the section shows an intersection pattern as the water table elevation criss-crosses the topographic surface. This indicates the presence of a river, stream or water body. When this was compared with the drainage map, it became evident that the section ran across Oji River in the eastern part (Fig. VIII).

The second cross section C-D runs through Enugu-Agidi, Agulu and Ekwulobia in the northwest -southeast direction. The section (Fig. IX) shows an intersection pattern as the water table elevation criss-crosses the topographic surface. This indicates the presence of a water body. When this was compared with the drainage map, it became evident that the section ran across Agulu Lake in southern part.

Table 2: Water Table Relative to Mean Sea Level (MSL)

\begin{tabular}{|c|c|c|c|c|}
\hline $\mathrm{S} / \mathrm{N}$ & VES Location & Depth to water table with reference to mean sea level (m) & Topographic Elevation $(\mathrm{m})$ & Water table $(\mathrm{m})$ \\
\hline 1 & Ndiuno Obinofia & 50 & 250 & 200 \\
\hline 2 & Ndiagu Obinofia & -100 & 50 & 150 \\
\hline 3 & Ugwuoba & -25 & 50 & 75 \\
\hline 4 & Oji River & 35 & 50 & 15 \\
\hline 5 & Akpugo & 50 & 100 & 50 \\
\hline 6 & Inyi & 50 & 200 & 150 \\
\hline 7 & Ufuma & 10 & 50 & 40 \\
\hline 8 & Ekwulobia & 150 & 300 & 150 \\
\hline 9 & Obeledu & 234 & 400 & 166 \\
\hline 10 & Agulu & 160 & 200 & 40 \\
\hline 11 & Umuawulu & 45 & 100 & 55 \\
\hline 12 & Enugu Agidi & 45 & 100 & 55 \\
\hline 13 & Mgbakwu & -50 & 50 & 100 \\
\hline
\end{tabular}




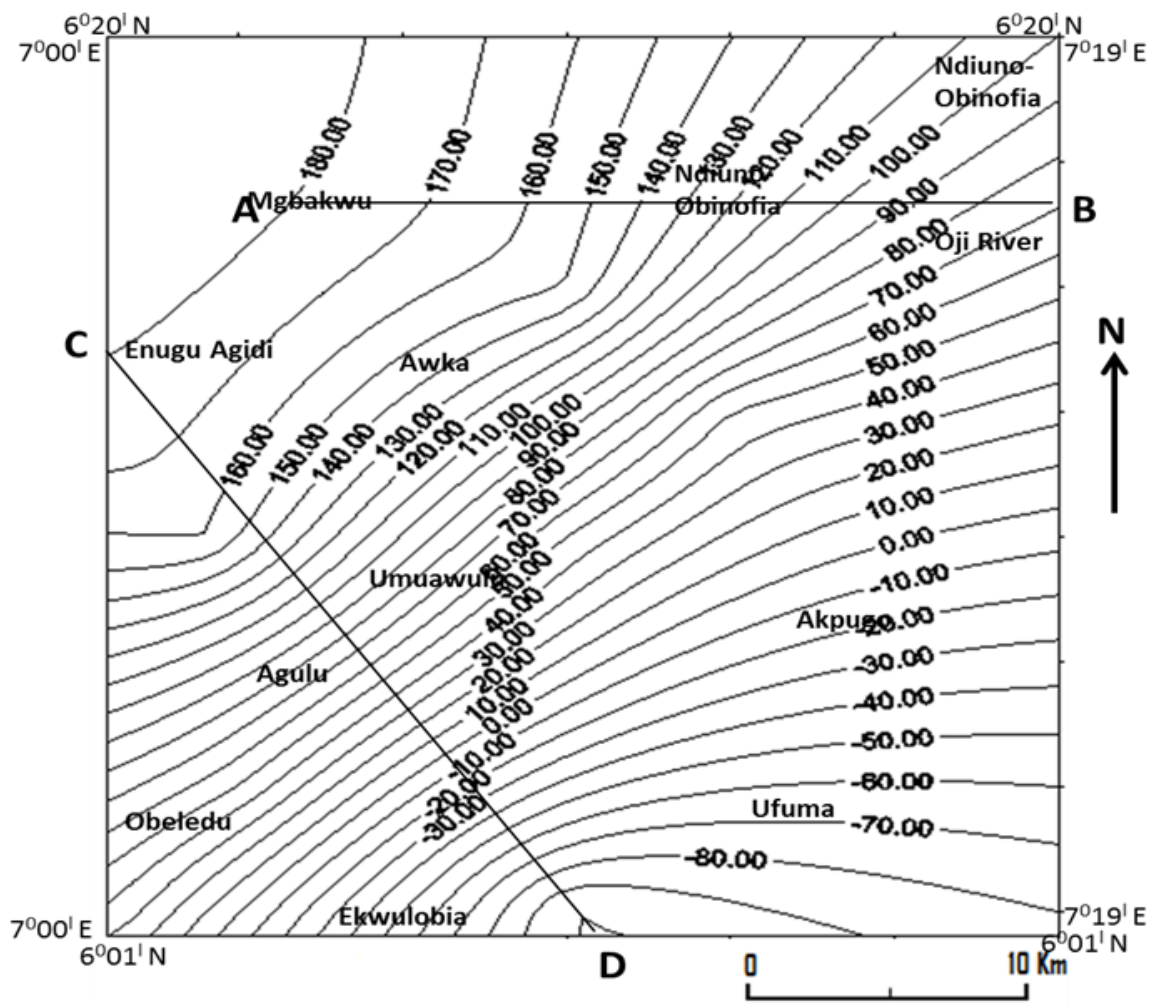

Fig. 8: Water Table Map of the Study Area (Contour Interval 10m)

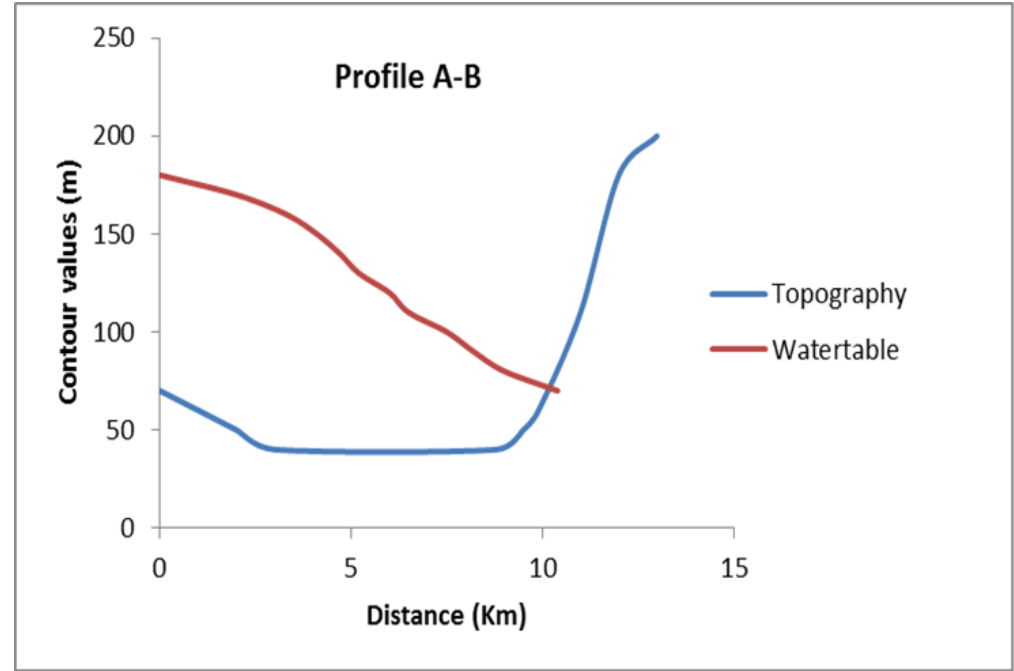

Fig. 11: A) Comparison of Cross Sections (A-B) Of Water Table and Topography

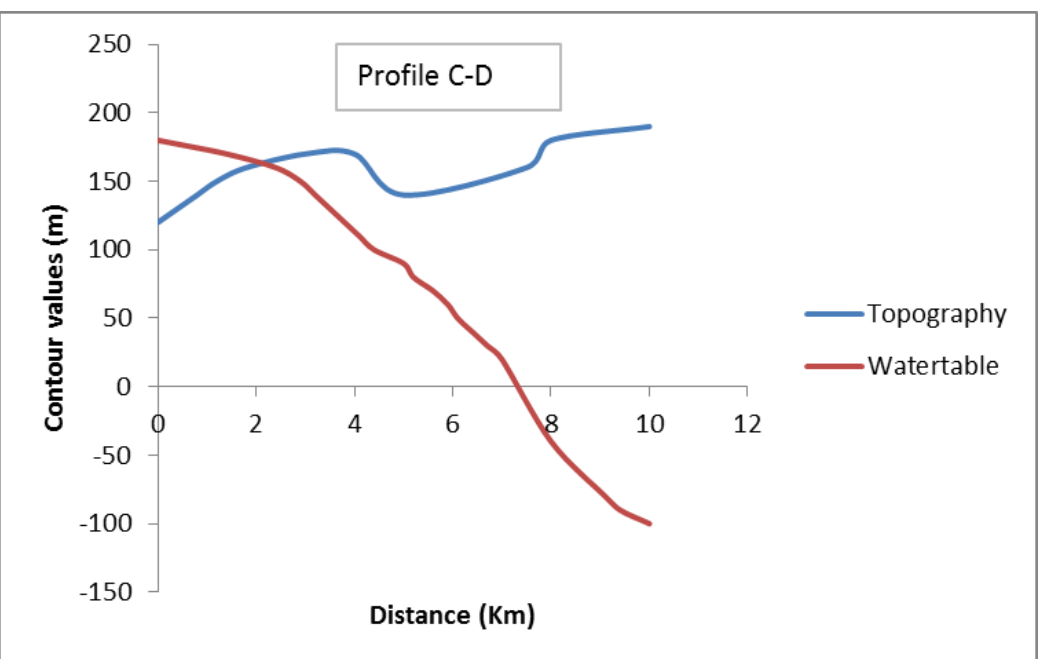

Fig. 11: B) Comparison of Cross Sections (C-D) Of Water Table and Topography 


\subsection{Aquifer parameter}

Knowledge of hydraulic conductivity and transmissivity is essential for the determination of natural water flow through an aquifer. Use of layer thickness, as derived from the interpretation of resistivity soundings data and hydraulic conductivity calculated on the basis of geophysical data led to the calculation of aquifer transmissivity. This technique was used for the determination of aquifer parameters in some parts of Anambra and Enugu States.

Aquifer transmissivity TC in groundwater hydrology is given by (Niwas, and Singhal, 1981):

$\mathrm{TC}=\mathrm{KCb}$

Where $\mathrm{b}$ is the aquifer thickness. Hydraulic conductivity $\mathrm{K}$, obtained at each sounding position and the aquifer thickness $b$, resulting from multilayer resistivity models, were used to derive the transmissivity TC, according to equation (1). The variation of TC across the aquiferous zone of the investigated area is shown in
Table III and Fig. X. Maps of the transmissivity, hydraulic conductivity and transverse resistance provided the means to identify areas where the aquiferous zone is prolific.

A relationship is expected if we try to relate transmissivity and transverse resistance maps of Figs. X and XII. Transmissivity values in Figure 10 vary between $4.8 \times 10-2$ to $5.90 \times 10-1 \mathrm{~m} 2 /$ day, suggesting a high quality reservoir. The knowledge of Transmissivity distribution is a fundamental source of information for establishing a hydrogeological model. Also, the transverse resistance map (Fig. XII) shows clearly the region that should be avoided during groundwater exploration due to the high resistance of about 180, $000 \mathrm{Ohm}-\mathrm{m} 2$ especially around Inyi town.

Relating the transmissivity distribution (Figure 10) and hydraulic conductivity map (Fig. XI), it is evident that there are high transmissivities and high hydraulic conductivities at Oji-River area. This confirms the prolific nature of the Ajali Sandstone, which underlies the area.

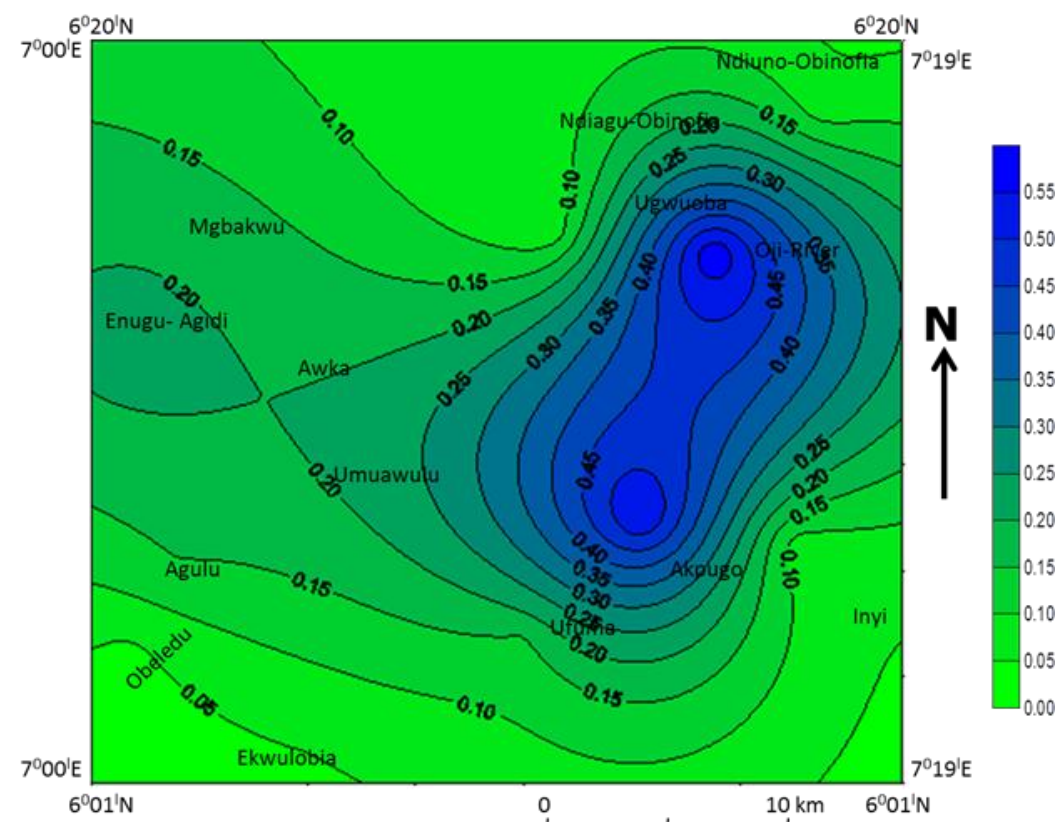

Fig. 12: Transmissivity Map of the Study Area

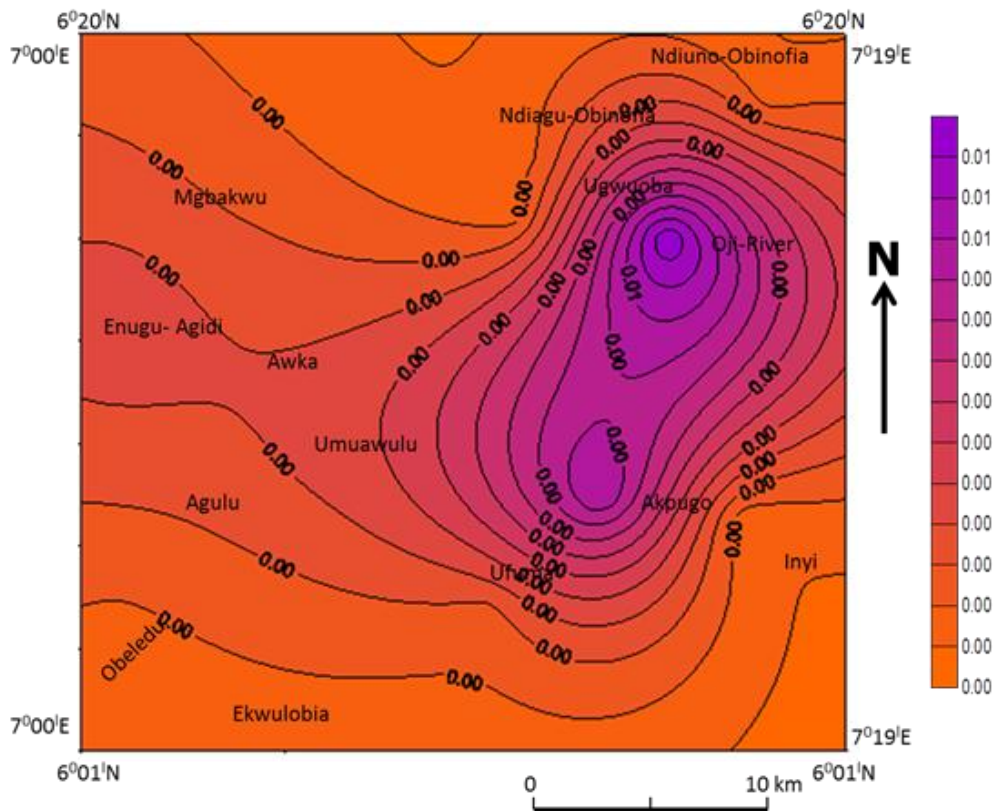

Fig. 13: Hydraulic Map of the Study Area 


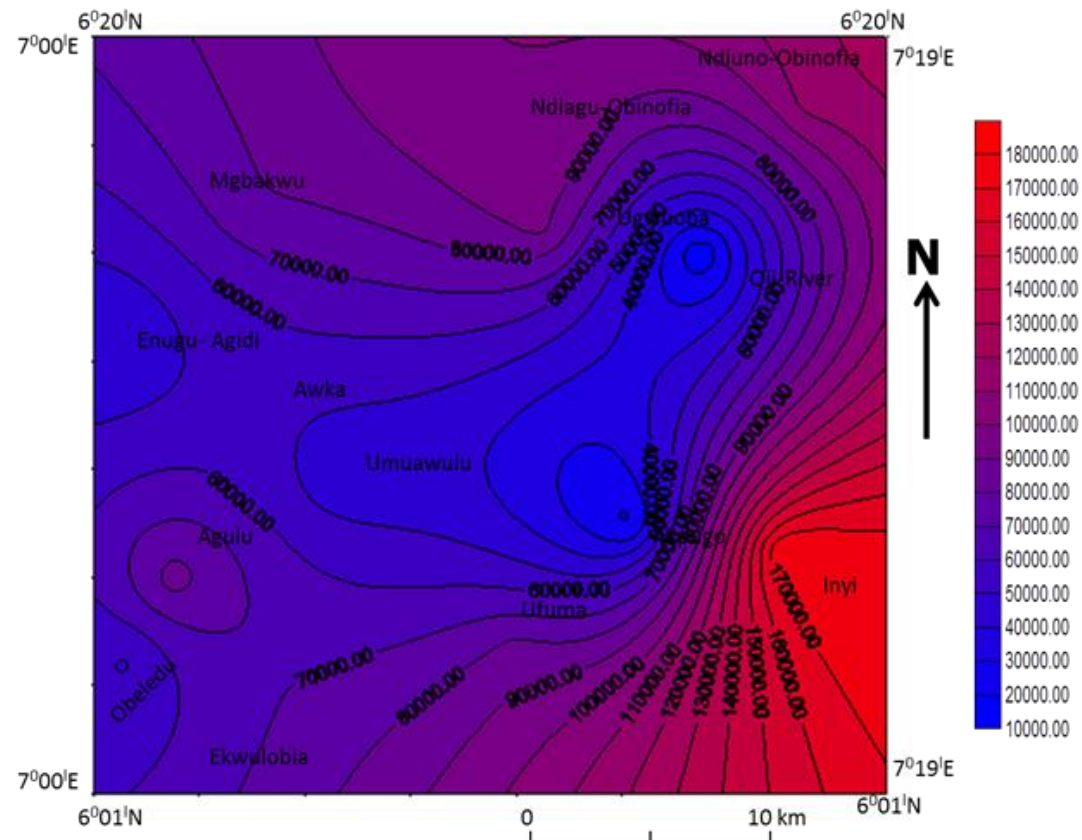

Fig. 14: Transverse Resistance Map of the Study Area

Table 3: Calculated Aquifer Parameters from the VES Data

\begin{tabular}{|c|c|c|c|c|c|c|}
\hline $\begin{array}{l}\text { VES } \\
\text { NO }\end{array}$ & $\begin{array}{l}\text { Aquifer thick- } \\
\text { ness }(\mathrm{m})\end{array}$ & $\begin{array}{l}\text { Interpreted Resistivi- } \\
\text { ty }(\Omega \mathrm{m})\end{array}$ & $\begin{array}{l}\text { Transverse Resistance } \\
\left(\mathrm{Ohm}-\mathrm{m}^{2}\right)\end{array}$ & $\begin{array}{l}\text { Longitudinal Con- } \\
\text { ductance } \\
\left(\Omega \mathrm{m}^{-1}\right)\end{array}$ & $\begin{array}{l}\text { Hydraulic Conductivity } \\
\text { (m/day) }\end{array}$ & $\begin{array}{l}\text { Transmissivity } \\
\left(\mathrm{m}^{2} / \text { day }\right)\end{array}$ \\
\hline 1 & 90 & 1250 & 112500 & 0.072 & 0.0008 & 0.072 \\
\hline 2 & 98 & 950 & 93100 & 0.103 & 0.0011 & 0.103 \\
\hline 3 & 75 & 1220 & 91500 & 0.061 & 0.0008 & 0.061 \\
\hline 4 & 85 & 144 & 12240 & 0.590 & 0.0069 & 0.590 \\
\hline 5 & 100 & 180 & 18000 & 0.556 & 0.0056 & 0.556 \\
\hline 6 & 120 & 1500 & 180000 & 0.080 & 0.0007 & 0.080 \\
\hline 7 & 110 & 760 & 83600 & 0.145 & 0.0013 & 0.145 \\
\hline 8 & 60 & 1250 & 75000 & 0.048 & 0.0008 & 0.048 \\
\hline 9 & 44 & 1125 & 49500 & 0.039 & 0.0009 & 0.039 \\
\hline 10 & 110 & 768 & 84480 & 0.143 & 0.0013 & 0.143 \\
\hline 11 & 95 & 466 & 44270 & 0.204 & 0.0021 & 0.204 \\
\hline 12 & 95 & 420 & 39900 & 0.226 & 0.0024 & 0.226 \\
\hline 13 & 110 & 709 & 77990 & 0.155 & 0.0014 & 0.155 \\
\hline
\end{tabular}

\section{Conclusion}

Resistivity survey was conducted in thirteen communities in both Anambra and Enugu states in order to ascertain the groundwater potential of the area. The hydrogeological investigation of the area revealed three to five geo-electric units in which the lowermost unit serves as the aquifer. Lithologic log from a borehole in the area revealed that some of the geologic units were suppressed or merged as a single geo-electric unit in the VES curves. This is due to their similarities in electrical resistivity. Generally, the geoelectric sections show favourable relationship with the lithologic units from the borehole. The water table map shows multi-flow directions which include E-W, W-E, S-N and N-S directions. The water table elevation also follows the trend of the topography. The results of the investigation will serve as a useful guide to agencies and managers in water resources planning and development of the area.

\section{References}

[1] Aboh, H. O. and Osazuwa, I. B. 2000. Lithological deductions from Regional Geoelectric Investigation in Kaduna, Kaduna State Nigeria. Nigerian Journal of Physics 12:1-7.

[2] Adiat, K. A. N; Olayanju, G. M; Omosuyi G.O. and Ako B.D. 2009. Electromagnetic profiling and electrical resistivity soundings in groundwater investigation of a typical Basement Complex - A case study of Oda town Southwestern Nigeria; Ozean Journal of Applied Sciences, 2 (4):333-359.
[3] Akpoborie, I. A., Nfor, B., Etobro, A.A.I. and Odagwe, S. 2011. Aspects of the geology and groundwater conditions of Asaba, Nigeria; Archives of Applied Science Research, 3(2): 537-550.

[4] Amaresh, K.S.; Raviprakash, S.; Mishra, D.; and Singh, S. 2006. Groundwater potential modeling in Chandraprabha subwater shed, using remote sensing, geoelectrical and GIS. Www.gisdevelopment.net. Retrieved Aug. 2007.

[5] Anudu, G. K., Onwuemesi, A. G., Ajaegwu, N.E., Onuba, L. N. and Omali, A.O. 2008. Electrical resistivity investigation for groundwater in the basement complex terrain: a case study of Idi-Ayunre and its environs, Oyo State, Southwestern Nigeria. Natural and Applied Sciences Journal, 9(2): 1-12

[6] Cratchley, C. R. and Jones, G. P. 1965. An interpretation of the Geology and gravity anomalies of the Benue Valley, Nigeria. Oversea Geol. Surv. Geophys. Paper, No.1.

[7] Edet, A. E and Okereke, C. 2002. "Delineation of shallow groundwater aquifers in the coastal plain sands of Calabar area (Southern Nigeria) using surface resistivity and hydrogeological data". Journal of African Earth Sciences. 35:433-443.

[8] Ekwe, A. C., Onu, N. N. and Onuorah, K. M. 2006. Estimation of aquifer hydraulic characteristics from electrical sounding data: The case of middle Imo River Basin aquifer, Southeastern Nigeria Journal of spatial hydrology, 6( 2):28-35.

[9] Emenike, E. A. 2000. "Geophysical Exploration for Groundwater in a Sedimentary Environment”: A case study from Nanka over Nanka Formation in Anambra Basin, Southeastern Nigeria. Global Jour. Pure and Applied. Sciences. 7(1):97-110.

[10]Ezeh , C. C. 2011. Geoelectrical studies for estimating aquifer hydraulic properties in Enugu State, Nigeria. International Journal of the Physical Sciences, 6(14): 3319-3329.

[11]Grant, N. K. 1971. South Atlantic, Benue Trough and Gulf of Guinea triple junction. Bull. Geol.Soc. Amer, 82:.2295-2298. 
[12]Lucas F. A. and Ishiekwene, E. 2010. Miospore (Pollen and Spore) Biozonation Model for Late Cretaceous -Tertiary Succession of Gbekebo-LWell, Benin Flank, Anambra Basin Nigeria. World Journal of Applied Science and Technology, 2(2), p303 - 308.

[13]Mohammed, I. N, Aboh, H. O. and Emenike, E. A. 2008 Hydrogeophysical investigation for groundwater potential in central Minna, Nigeria. Science World Journal, 3(4):49-54.

[14]Montgomery, D. 2000. The present state of industrial statistics. Quality and Reliability Engineering International, 16(4): 253-254.

[15]Murat, R. C., 1970. Stratigraphy and Paloegeography of the Cretaceous and Lower Tertiary Sediments in Southern Nigeria. In: Dessuvagie, T. F J and Whiteman, A. J(ed) Ibid. 251: 105-113.

[16]Niwas, S., and Singhal, D.C. 1981. Estimation of aquifer transmissivity from Dar Zarrouk parameters in porous media. Hydrology, 50:393-399.

[17]Okoro, E. I.; Egboka, B. C. E. And Onwuemesi, A.G. 2010. Evaluation of the aquifer characteristics of Nanka Sands using hydrogeological method in combination withvertical electrical sounding (VES), Jour. Appl. Sci. Environ. Manage. 14 (2):5 - 9.

[18]Onwuemesi, A. G. And Egboka, B. C. E. 2006. 2-D polynomial curve fitting techniques on water table and hydraulic gradients estimations in parts of Anambra Basin, Southern Nigeria. Natural and Applied sci. jour. 8, (1):6-13.

[19]Oseji, J. O. And Ujuanbi, O. 2009. Hydrogeophysical investigation of groundwater potential in Emu kingdom, Ndokwa land of Delta State,Nigeria. International Journal of Physical Sciences, 4, (5):275284.

[20]Van Overmeeren, R.A. 1989. Aquifer boundaries explored by geoelecrtrical measurements in the coastal plain of Yemen: A Case of Equivalence. Geophysics. 54(1):38-48 